\title{
Pinpointing brainstem mechanisms responsible for autonomic dysfunction in Rett syndrome: therapeutic perspectives for 5- $\mathrm{HT}_{1 \mathrm{~A}}$ agonists
}

\author{
Ana P. Abdala ${ }^{1 *}$, John M. Bissonnette ${ }^{2}$ and Adrian Newman-Tancredi ${ }^{3}$ \\ ${ }^{1}$ School of Physiology and Pharmacology, University of Bristol, Bristol, UK \\ ${ }^{2}$ Department of Obstetrics and Gynecology, Oregon Health and Science University, Portland, OR, USA \\ ${ }^{3}$ Neurolixis Inc., Dana Point, CA, USA
}

\section{Edited by:}

Thiago S. Moreira, University of Sao

Paulo, Brazil

\section{Reviewed by:}

Chao Chen, University of California, Davis, USA

Angela J. Grippo, Northern Illinois University, USA

${ }^{*}$ Correspondence:

Ana P. Abdala, School of Physiology and Pharmacology, University of

Bristol, Medical Sciences Building, University Walk, Bristol

BS8 1TD, UK

e-mail:ana.abdala@bristol.ac.uk
Rett syndrome is a neurological disorder caused by loss of function of methyl-CpG-binding protein 2 (MeCP2). Reduced function of this ubiquitous transcriptional regulator has a devastating effect on the central nervous system. One of the most severe and life-threatening presentations of this syndrome is brainstem dysfunction, which results in autonomic disturbances such as breathing deficits, typified by episodes of breathing cessation intercalated with episodes of hyperventilation or irregular breathing. Defects in numerous neurotransmitter systems have been observed in Rett syndrome both in animal models and patients. Here we dedicate special attention to serotonin due to its role in promoting regular breathing, increasing vagal tone, regulating mood, alleviating Parkinsonian-like symptoms and potential for therapeutic translation. A promising new symptomatic strategy currently focuses on regulation of serotonergic function using highly selective serotonin type 1A (5-HT $1 \mathrm{~A})$ "biased agonists." We address this newly emerging therapy for respiratory brainstem dysfunction and challenges for translation with a holistic perspective of Rett syndrome, considering potential mood and motor effects.

Keywords: Rett syndrome, $5-\mathrm{HT}_{1 \mathrm{~A}}$ receptor, breathing, anxiety, motor activity, serotonin, brainstem, vagal tone
Rett syndrome (RTT) is a neurological disorder caused by loss of function of methyl-CpG-binding protein 2 (MeCP2). This syndrome is most often linked to mutations in the $\mathrm{X}$ linked gene that encodes this protein. The loss of function of this ubiquitous transcriptional regulator has a devastating effect in particular on the central nervous system. The syndrome presents with cortical features, including severe mental disability and epilepsy (Dolce et al., 2013); and extrapyramidal symptoms, resulting in dystonia and dyskinesia (Chahrour and Zoghbi, 2007). However, a life-threatening presentation of this syndrome is the brainstem dysfunction, which results in breathing disturbances. This phenotype, mimicked by the mouse models of RTT, is deemed the most reliable outcome measure for clinical translation (Katz et al., 2012). Like most phenotypes in RTT, the presentation of respiratory disturbances is highly variable, but typically includes episodes of breathing cessation interspersed with hyperventilation or irregular breathing (Ramirez et al., 2013). Defects in various neurotransmitter systems have been observed in patients and animal models of Rett syndrome (Weng et al., 2011), but we believe serotonin (5-HT) deserves particular interest due to its role in promoting regular breathing and potential for translation. A "silver bullet" is unlikely to exist but a promising symptomatic strategy currently focuses on regulation of serotonergic function using highly selective serotonin type $1 \mathrm{~A}$ agonists $\left(5-\mathrm{HT}_{1 \mathrm{~A}}\right)$. Here we address this newly emerging therapy for respiratory brainstem dysfunction in Rett syndrome and challenges for translation with a holistic perspective.

\section{SEROTONIN AND AUTONOMIC CONTROL IN RETT SYNDROME}

Deficiencies of 5-HT neurotransmission have been found both in humans suffering from Rett syndrome and in mouse models of the disease. In women with known MeCP2 mutations who met the clinical criteria for Rett syndrome, low spinal fluid levels of a 5-HT metabolite were found (Samaco et al., 2009). Low levels of 5-HT were also found in the brain of MeCP2 knockout male mice and were progressive with development (Ide et al., 2005; Viemari et al., 2005). But brain concentrations of tryptophan, the serotonin precursor, were comparable to wild-type control mice suggesting a failure of biosynthesis of serotonin (Ide et al., 2005).

Serotonin is an important regulatory neurotransmitter in the respiratory network. Generally it has a modulatory effect on breathing, increasing or decreasing post-synaptic excitability depending on the types of receptors expressed. Overall, the effect of 5-HT results in net stimulation of ventilation, and it is a significant component of ventilatory responses to $\mathrm{CO}_{2}$ (Richerson, 2004). Global deletion or acute inhibition of serotoninergic neurons in mice results in blunted respiratory responses to $\mathrm{CO}_{2}$ challenges (Hodges et al., 2008; Ray et al., 2011). Deletion of MeCP2 in male mice reduced $\mathrm{CO}_{2}$ sensitivity (Zhang et al., 2011) and selective blockade of serotonin re-uptake with citalopram corrected it (Toward et al., 2013). Recently, female mice with two different MeCP2 mutations have shown depressed $\mathrm{CO}_{2}$ chemosensitivity (Bissonnette et al., 2014). Imbalance in $\mathrm{CO}_{2}$ homeostasis was also found in human patients (Smeets et al., 2006). Forceful breathing and 
hyperventilation are a common occurrence in between episodes of apnea, and often result in hypocapnia (Smeets et al., 2006; Halbach et al., 2012). This combined with an upwards-shifted apneic threshold (Toward et al., 2013) could contribute to episodes of central apnea and oxygen desaturation (Southall et al., 1988). Hypocapnia and low oxygen can be powerful triggers of seizures or epilepsy-like episodes in Rett syndrome. In one patient, described as a forceful breather with epochs of Valsalva maneuvers, such episodes were successfully managed by administration of $\mathrm{CO}_{2}$ to correct hypocapnia (Smeets et al., 2006).

In addition to $\mathrm{CO}_{2}$ homeostasis, serotonin is also thought to promote regular breathing via activation of $5-\mathrm{HT}_{1 \mathrm{~A}}$ receptors in key brainstem sites involved in termination of inspiration (Richter et al., 2003). A 5-HT $1 \mathrm{~A}$ partial agonist, buspirone, has been used to treat apneusis caused by surgical resection of a pontine astrocytoma in human (Wilken et al., 1997) and abnormal breathing in Rett syndrome (Andaku et al., 2005; Gokben et al., 2012). Systemic administration of a $5-\mathrm{HT}_{1 \mathrm{~A} / 7}$ agonist, (R)-(+)-8-hydroxy-2-(di-n-propylamino) tetralin hydrobromide (+8-OH-DPAT) has also abolished spontaneous central apneas both in wild-type mice (Stettner et al., 2008) and MeCP2 deficient female mice (Abdala et al., 2010). More recently, systemic administration of $5-\mathrm{HT}_{1 \mathrm{~A}}$ agonists produced some of the most robust rescue of respiratory phenotype yet observed in multiple mouse models of Rett syndrome (Levitt et al., 2013; Abdala et al., in press).

Figure 1 summarizes multiple suggested mechanisms for generation of breathing irregularity in Rett syndrome observed in mouse models and the potential ponto-medullary targets for 5$\mathrm{HT}_{1 \mathrm{~A}}$ agonists. It is noteworthy that 5-HT receptors are expressed in diverse brainstem regions and can mediate additive or opposing effects on respiratory control. For instance, activation of $5-\mathrm{HT}_{1 \mathrm{~A}}$ somatodendritic autoreceptors on raphe serotoninergic neurons reduced $\mathrm{CO}_{2}$ sensitivity (Corcoran et al., 2013) a potentially undesirable effect in RTT. However, a selective agonist of $5-\mathrm{HT}_{1 \mathrm{~A}}$ post-synaptic heteroreceptors effectively corrected the respiratory phenotype in a mouse model of RTT (Levitt et al., 2013). This suggests that the beneficial effects of $5-\mathrm{HT}_{1 \mathrm{~A}}$ agonists on breathing are chiefly mediated by heteroreceptors.

Serotonin is also important for cardiac sympatho-vagal balance. Serotoninergic agonists shift the equilibrium between cardiac sympathetic and vagal drives toward the latter, which has a protective effect against ventricular fibrillation (Lehnert et al., 1987; McCall et al., 1994; Chen et al., 2008). Chen et al. (2008) showed that a $5-\mathrm{HT}_{1 \mathrm{~A} / 7}$ agonist disinhibited vagal motor neurons via reduction of inputs from inhibitory neurons. In mice, deletion of $5-\mathrm{HT}_{1 \mathrm{~A}}$ receptors increased the susceptibility to sudden cardiac death under chronic stress (Carnevali et al., 2012). Interestingly, girls with Rett syndrome present reduced heart rate variability, as consequence of a reduced vagal tonus, which correlated with lower plasma levels of serotonin (Guideri et al., 1999, 2004). The reduced vagal tonus is progressive with development and clinical stage, and may explain the high risk of sudden death in Rett syndrome (Kerr et al., 1997; Guideri et al., 2001). In a cohort of patients with normal cardiac vagal drive, the increase of vagal tonus induced

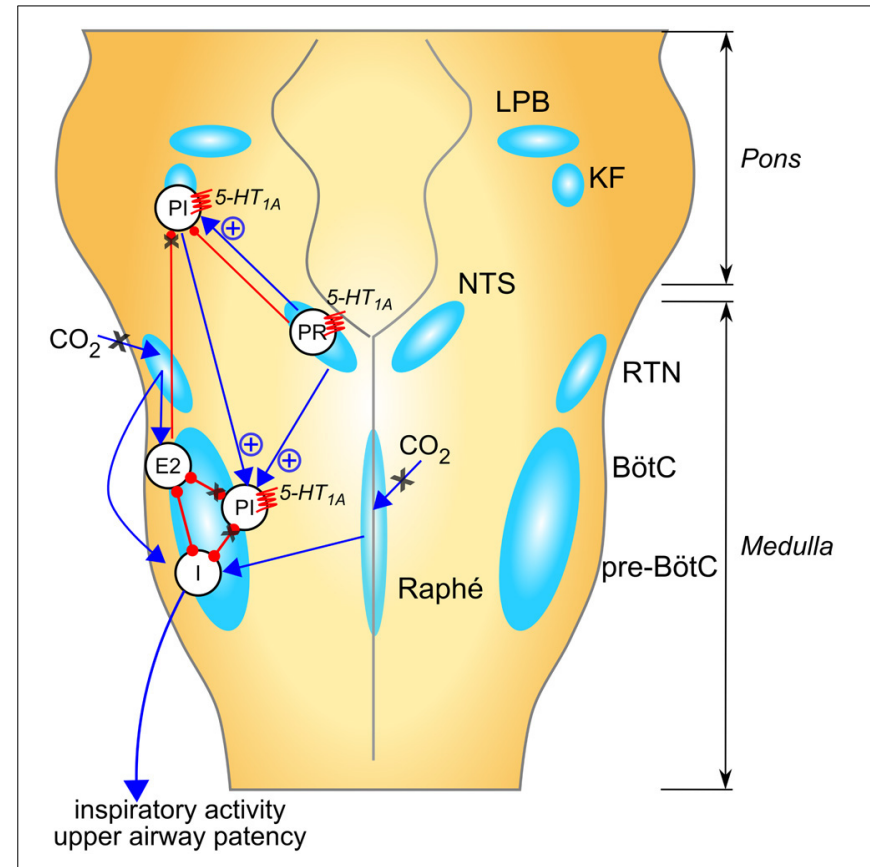

FIGURE 1 | Suggested mechanisms for respiratory rhythm disease in Rett syndrome and network targets of $\mathbf{5}-\mathbf{H T}_{\mathbf{1 A}}$ agonists. Populations of respiratory neurons are shown in white circles (see below). Blue arrows indicate excitatory drive; red connectors with circle-ends indicate inhibitory drive. A healthy respiratory rhythm and pattern are critically dependent on the balance between excitatory and inhibitory synaptic drives to the "core" of mutually inhibitory respiratory neurons located in the BötC and pre-BötC (Smith et al., 2013). The disturbed rhythm in Rett syndrome seems to arise from an imbalance of drives to this core circuitry (indicated by black " $X$ " when reduced, or blue "+" when enhanced); many mechanisms contribute to this: (i) weakened excitatory synaptic drives to and within the inspiratory "kernel" (Viemari et al., 2005), (ii) reduced $\mathrm{CO}_{2}$ sensitivity (Zhang et al., 2011; Toward et al., 2013; Bissonnette et al., 2014); (iii) excess descending post-inspiratory drive from the pontine parabrachial complex (Stettner et al., 2007; Voituron et al., 2010; Dhingra et al., 2013); which could be a consequence of loss of inhibitory drives to this area, including KF (Stettner et al., 2007; Abdala et al., 2010). In combination, these mechanisms would lead to disinhibition of Pl populations, disruption of timing for termination of inspiration and expiratory length irregularity. Studies in humans and mice suggest that breath-holds and Valsalva maneuvers may be linked to active closure of the glottis implicating a failure in the ponto-medullary gating of central post-inspiratory activity, for a review; see Ramirez et al. (2013). $5-\mathrm{HT}_{1 \mathrm{~A}}$ receptors suppress specific inhibitory glycinergic neuron populations in the "core" of mutually inhibitory neurons with consequent disinhibition of inspiratory populations (Shevtsova et al., 2011). In addition, $5-\mathrm{HT}_{1 \mathrm{~A}}$ receptors can directly reduce the activity of neuron populations contributing to the descending post-inspiratory drive from the pons. I, inspiratory neuron population; $\mathrm{Pl}$, post-inspiratory neuron population; E2, late expiratory neuron population; PR, pulmonary stretch relay; LBP, lateral parabrachial nu; KF, Kölliker-Fuse nu; NTS, nucleus of the solitary tract; RTN, retrotrapezoid nu; BötC, Bötzinger complex; pre-BötC, pre-Bötzinger complex.

by selective $5-\mathrm{HT}_{1 \mathrm{~A}}$ agonists would be an undesirable side effect, placing them at risk of atrial arrhythmias. In patients with Rett syndrome, who display a shifted set point of cardiac parasympathetic drive, the increase of vagal tonus induced by selective $5-\mathrm{HT}_{1 \mathrm{~A}}$ agonists would be a particularly desirable effect. 


\section{SLEEP DISORDERED BREATHING IN RETT SYNDROME}

Another likely contributor for sympathetic overactivity in Rett syndrome is sleep disordered breathing. Recent polysomnography recordings in girls with Rett syndrome revealed that obstructive sleep apneas (OSAs) are highly prevalent in this population. During sleep, central apneas are less frequent and shorter when compared to wakefulness (Weese-Mayer et al., 2008). Even though central apneas are 10-30\% more frequent than OSAs during sleep, the latter are clinically relevant in approximately $50 \%$ of the patients investigated, causing life threatening oxygen desaturations $\left(\mathrm{SpO}_{2}<75 \%\right)$ (Hagebeuk et al., 2012; Carotenuto et al., 2013). In children, severe OSA has clear health implications, the common symptoms are: frequent awakenings, night terrors, poor concentration, irritability, behavioral problems, failure to thrive, enuresis, attention-deficit disorder, cardiopulmonary disease, and excessive daytime sleepiness (Waters et al., 2013). Most of these symptoms are easily confounded with the symptomatology of Rett syndrome itself. Unfortunately, this means that often, from a clinician's point of view, OSA diagnosis and treatment is not a priority in Rett patients.

In fact, the high prevalence of OSAs is relevant for the treatment of respiratory disturbances in Rett syndrome since they have potential to generate a reciprocal feedback loop with central apneas resulting in respiratory irregularities. It is well established that OSAs increase peripheral chemoreceptor sensitivity in humans independently of other underlying conditions (Narkiewicz et al., 1999). In turn, excess activation of the peripheral chemoreceptor reflex during apnea-induced desaturations in Rett syndrome, could aggravate hyperventilation episodes in between apneas and generate hypocapnia. This type of respiratory overshoot is particularly undesirable during sleep, as $\mathrm{PaCO} 2$ reaches the apneic threshold resulting in periodic breathing (Dempsey et al., 2014). An overactive chemoreflex could also account for the sympatho-vagal imbalance common in patients with Rett (Guideri et al., 1999).

A pharmacotherapy capable of addressing all legs of this feedback loop would stand better chances of success in clinical practice. It is thought that, in the supine position, recruitment of the genioglossus can open a collapsed airway before arousal (Younes et al., 2012). For that reason, mechanisms that facilitate recruitment of hypoglossal motor neurons are an attractive target for pharmacotherapy. Rodent models revealed that the respiratory component of genioglossal activity is increased by $5-\mathrm{HT}_{1 \mathrm{~A}}$ receptor activation, a potentially beneficial effect (Besnard et al., 2007). Another potentially advantageous effect of this class of drugs is the reduction of epochs of REM sleep (Monti and Monti, 2000), since OSAs mostly occur in this phase. The lack of success in previous clinical trials (Kohler et al., 2009) using various older serotonin agonists may be due to their lack of receptor selectivity, weak partial agonism and/or poor pharmacokinetics (Fiorino et al., in press).

\section{SEROTONIN AND MOOD CONTROL IN RETT SYNDROME}

Particularly in Rett syndrome, mood disorder should not be viewed as a separate entity to autonomic dysfunction, as anxiety features could have a role in episodes of hyperventilation. Southall et al. (1988) observed that hyperventilation only occurred in wakefulness and was not necessarily preceded by hypoxemia, which suggests a central origin. Prolonged absences of inspiratory effort always followed hyperventilation. These girls also seemed agitated with increased muscle tonus and elevated heart rate, suggesting that anxiety may underlie these symptoms. SSRIs such as citalopram or fluoxetine are commonly used to treat anxiety disorders in a clinical setting. By preventing reuptake of 5 -HT, these drugs modify serotonin levels and, indirectly, activation of serotonin receptors. It should also be noted that 5-HT receptors are expressed in diverse brain regions and can mediate complementary or sometimes opposing influence on mood and cognition (Newman-Tancredi, 2011). For example, activation of $5-\mathrm{HT}_{1 \mathrm{~A}}$ autoreceptors in the raphe nuclei can totally suppress electrical activity of serotonergic neurons and thus powerfully inhibit serotonin release in neuronal projection areas (Celada et al., 2013). In contrast, activation of post-synaptic cortical $5-\mathrm{HT}_{1 \mathrm{~A}}$ heteroreceptors expressed on glutamatergic pyramidal cells and/or GABAergic interneurons, elicits increased dopamine release in cortex (Santana et al., 2004; Bortolozzi et al., 2010), an effect which is associated with beneficial effects on mood deficits as well as positive effects on cognitive function (Phillips et al., 2004).

In the case of RTT patients, lower basal levels of 5-HT are reported (see above) and some of the mood deficits observed in Rett syndrome patients may therefore arise from deficiencies in serotonergic transmission (particularly via $5-\mathrm{HT}_{1 \mathrm{~A}}$ receptors) in specific brain regions. Such a hypothesis is reinforced by transgenic mouse studies that have provided insight into the developmental role of $5-\mathrm{HT}_{1 \mathrm{~A}}$ receptors (Akimova et al., 2009; Garcia-Garcia et al., 2014). Thus, mice with a geneticallyelicited deletion of $5-\mathrm{HT}_{1 \mathrm{~A}}$ receptors $\left(5-\mathrm{HT}_{1 \mathrm{~A}} \mathrm{KO}\right.$ mice) exhibit heightened anxiety-like behavior, as do mice with a heterozygote $5-\mathrm{HT}_{1 \mathrm{~A}}$ genotype that express about half of normal levels of $5-\mathrm{HT}_{1 \mathrm{~A}}$ receptor density. This suggests that even partial decreases in $5-\mathrm{HT}_{1 \mathrm{~A}}$ receptor expression (which may mimic the impaired serotonergic transmission observed in Rett syndrome) can elicit phenotypically-meaningful increases in anxiety levels. In contrast, when mice were engineered to overexpress $5-\mathrm{HT}_{1 \mathrm{~A}}$ receptors (Kusserow et al., 2004), they exhibited the opposite phenotype, with decreased anxiety-like behavior and increased hippocampal and striatal levels of serotonin. An additional study investigated the reversal of the anxiety-like phenotype of $5-\mathrm{HT}_{1 \mathrm{~A}} \mathrm{KO}$ mice. In these mice, $5-\mathrm{HT}_{1 \mathrm{~A}}$ receptors were overexpressed in pyramidal neurons (but not GABAergic interneurons; Gross et al., 2002), in various forebrain regions, and this re-established normal behavioral responses. This study is significant because it shows that the "anxious" phenotype of the $\mathrm{KO}$ mice can be rescued, if $5-\mathrm{HT}_{1 \mathrm{~A}}$ receptor signaling is reintroduced to the relevant brain regions. Such observations support the assertion that treatments that augment $5-\mathrm{HT}_{1 \mathrm{~A}}$ receptor signaling in appropriate forebrain structures can attenuate anxiety symptoms.

The possibility that mood deficits seen in Rett syndrome patients arise from neurodevelopmental disruption of $5-\mathrm{HT}_{1 \mathrm{~A}}$ receptor expression is reinforced by studies showing that undisturbed expression of the $5-\mathrm{HT}_{1 \mathrm{~A}}$ receptor is required in the $2 \mathrm{nd}$ 
and 3rd week of life for the emergence of a normal anxiety-like phenotype. Indeed, genetic disruption of $5-\mathrm{HT}_{1 \mathrm{~A}}$ receptors in mice at this time period elicits development of pathological levels of anxiety (Gross et al., 2002; Leonardo and Hen, 2008), an observation that can be mimicked by pharmacological blockade of 5- $\mathrm{HT}_{1 \mathrm{~A}}$ receptors (Lo Iacono and Gross, 2008).

Taken together, the above considerations suggest that activation of $5-\mathrm{HT}_{1 \mathrm{~A}}$ receptors by administration of agonist drugs to Rett patients could attenuate anxiety symptoms in adults. In addition, if the heightened anxiety symptoms are the result of insufficient serotonergic activation during development, it may be speculated that treatment with a $5-\mathrm{HT}_{1 \mathrm{~A}}$ agonist at a young age may exert some measure of protection against the emergence of later anxiety symptoms. Nevertheless, considerable additional investigation is necessary to substantiate such hypotheses, notably because none of the above studies on transgenic $5-\mathrm{HT}_{1 \mathrm{~A}}$ mice was carried out in female $\mathrm{MeCP} 2^{+/-}$mice modeling Rett syndrome.

Indeed, studies of anxiety-like behavior in $\mathrm{MeCP} 2^{+/-}$mice have yielded somewhat divergent data. One study found that MeCP2 $2^{+/-}$female mice exhibited lower anxiety-like behavior in two different tests (Samaco et al., 2013). In contrast, another study in male mice expressing a truncated allele of $\mathrm{MeCP} 2$ $\left(\mathrm{MeCP} 2^{108 / y}\right.$ ) (McGill et al., 2006) found that MeCP2 $2^{+/-}$mice show responses that are typical of increased anxiety in the same tests. The relationship between these observations and the heightened anxiety observed in individuals with Rett syndrome is unclear, but there is a clear need for additional investigation of anxiety-like behavior in RTT mice, particularly in response to clinically-employed anxiolytic drugs and $5-\mathrm{HT}_{1 \mathrm{~A}}$ receptor agonists.

\section{DOPAMINERGIC INTERACTIONS OF SEROTONINERGIC AGONISTS: IMPLICATIONS FOR MOTOR FUNCTION IN RETT SYNDROME}

In women with known $\mathrm{MeCP} 2$ mutations who met the clinical criteria for Rett syndrome, low spinal fluid levels of a dopamine metabolite were found (Samaco et al., 2009). Assuming that this is a marker for central dopamine levels, it may provide a neurochemical substrate for the devastating disturbances in motor function observed in Rett syndrome, characterized by loss of purposeful use of the hands, ataxia, tremors, gait apraxia, rigidity, and dystonia. Another indicator of compromised dopaminergic

Table 1 | Drugs currently under clinical testing that possess serotonin $5-\mathrm{HT}_{1 \mathrm{~A}}$ receptor agonist activity.

\begin{tabular}{|c|c|c|c|c|c|}
\hline Drug & Clinical indication & $\begin{array}{l}\text { Trade name }{ }^{\circledR} \text { or } \\
\text { highest development }\end{array}$ & Company & Mechanism of action & References \\
\hline Buspirone & Anxiety (GAD) & Buspar $^{\circledR}$ & BMS & $\begin{array}{l}\text { 5- } \mathrm{HT}_{1 \mathrm{~A}} \text { partial agonist, } \mathrm{D}_{2} \\
\text { antagonist }\end{array}$ & Akimova et al., 2009 \\
\hline Tandospirone & Anxiety (GAD) & Sediel $^{\circledR}$ & $\begin{array}{l}\text { Dainippon } \\
\text { Sumitomo }\end{array}$ & $\begin{array}{l}\text { 5- } \mathrm{HT}_{1 \mathrm{~A}} \text { partial agonist, } \mathrm{D}_{2} \\
\text { antagonist }\end{array}$ & $\begin{array}{l}\text { Meltzer and } \\
\text { Sumiyoshi, } 2008\end{array}$ \\
\hline Vilazodone & Depression & Viibryd $^{\circledR}$ & $\begin{array}{l}\text { Clinical } \\
\text { Data }\end{array}$ & SRI, 5-HT $1 \mathrm{~A}$ partial agonist & $\begin{array}{l}\text { Dawson and } \\
\text { Watson, } 2009\end{array}$ \\
\hline Vortioxetine & Depression & Brintellix ${ }^{\circledR}$ & $\begin{array}{l}\text { Lundbeck/ } \\
\text { Takeda }\end{array}$ & $\begin{array}{l}\text { SRI; 5- } \mathrm{HT}_{1 \mathrm{~A}} \text { and } 5-\mathrm{HT}_{1 \mathrm{~B}} \text { partial } \\
\text { agonist; } 5-\mathrm{HT}_{1 \mathrm{D}}, 5-\mathrm{HT}_{3} \text { and } \\
\text { 5- } \mathrm{HT}_{7} \text { antagonist }\end{array}$ & Mork et al., 2009 \\
\hline Flibanserin & $\begin{array}{l}\text { Female hypoactive } \\
\text { sexual desire disorder }\end{array}$ & Phase III & Sprout & $\begin{array}{l}\text { 5- } \mathrm{HT}_{1 \mathrm{~A}} \text { agonist, } 5-\mathrm{HT}_{2 \mathrm{~A}} \\
\text { antagonist, } \mathrm{D}_{4} \text { partial agonist }\end{array}$ & Stahl et al., 2011 \\
\hline Sarizotan & $\begin{array}{l}\text { L- DOPA-induced } \\
\text { dyskinesia in } \\
\text { Parkinson's disease }^{a}\end{array}$ & Phase III & Newron & $\begin{array}{l}5-\mathrm{HT}_{1 \mathrm{~A}} \text { agonist, } \mathrm{D}_{2} \text { partial } \\
\text { agonist }\end{array}$ & $\begin{array}{l}\text { Bartoszyk et al., } \\
2004\end{array}$ \\
\hline Befiradol & $\begin{array}{l}\text { L- DOPA-induced } \\
\text { dyskinesia in } \\
\text { Parkinson's disease }\end{array}$ & Phase II & Neurolixis & Selective $5-\mathrm{HT}_{1 \mathrm{~A}}$ full agonist & Colpaert, 2006 \\
\hline Eltoprazine & $\begin{array}{l}\text { L- DOPA-induced } \\
\text { dyskinesia in } \\
\text { Parkinson's disease }\end{array}$ & Phase II & Amarantus & $\begin{array}{l}5-\mathrm{HT}_{1 \mathrm{~A}} \text { and } 5-\mathrm{HT}_{1 \mathrm{~B}} \text { partial } \\
\text { agonist, } 5-\mathrm{HT}_{2 \mathrm{~A}}, 5-\mathrm{HT}_{2 \mathrm{~B}} \\
5-\mathrm{HT}_{2 \mathrm{C}}\end{array}$ & Bezard et al., 2013 \\
\hline $\begin{array}{l}\text { NLX-101 } \\
(\text { F15599) }\end{array}$ & Rett syndrome & Phase I & Neurolixis & $\begin{array}{l}\text { Selective post-synaptic } 5-\mathrm{HT}_{1 \mathrm{~A}} \\
\text { "biased agonist" }\end{array}$ & Levitt et al., 2013 \\
\hline
\end{tabular}

GAD, Generalized Anxiety Disorder; SRI, Serotonin Reuptake Inhibitor.

a Sarizotan may also be developed for Rett syndrome (http://www.newron.com/eng/Default.aspx?SEZ=3\&PAG=141). 
transmission is that, later in life, the women with Rett develop Parkinsonian features (Fitzgerald et al., 1990; Roze et al., 2007).

The precise role of serotonin in Rett syndrome motor deficits in currently unclear but some analogies may be drawn from the use of serotonergic agonists in the treatment of Parkinson's disease (PD) - which is also characterized by dopaminergic deficiencies leading to motor impairment. For example (i) 5$\mathrm{HT}_{1 \mathrm{~A}}$ receptor agonists reverse catalepsy induced by blockade of dopamine receptors with neuroleptics (McMillen et al., 1988; Wadenberg, 1996); (ii) (+)-8-OH-DPAT and sarizotan reduced L-DOPA-induced dyskinesia in monkeys with lesioned dopaminergic neurons in the substantia nigra (Iravani et al., 2006; Gregoire et al., 2009; Marin et al., 2009); and (iii) in clinical trials, sarizotan, buspirone, and tandospirone alleviated dyskinesia in $\mathrm{PD}$ patients (Bonifati et al., 1994; Kannari et al., 2002). At a neurochemical level, $5-\mathrm{HT}_{1 \mathrm{~A}}$ receptor agonists increase dopamine release in frontal cortex, as mentioned above, and modify the activity of cortico-striatal glutamatergic projections. Such influence, possibly involving inhibition of glutamate in the striatum may underlie the capacity of $5-\mathrm{HT}_{1 \mathrm{~A}}$ receptor agonists to facilitate movement control (Dupre et al., 2011; Huot et al., 2011). Table 1 lists drugs currently under clinical testing that possess serotonin $5-\mathrm{HT}_{1 \mathrm{~A}}$ receptor agonist activity.

Insofar as such observations may be relevant to Rett syndrome, they suggest that activation of $5-\mathrm{HT}_{1 \mathrm{~A}}$ receptors may alleviate some of the disturbed motor function, including dyskinesia and dystonia, which constitute a source of poor movement control in RTT patients. Nevertheless, experimental investigation is necessary to substantiate this hypothesis, for example by examining the motor sensitivity of MeCP2 mice to dopamine receptor blockade (catalepsy induction) and whether $5-\mathrm{HT}_{1 \mathrm{~A}}$ receptor agonists can protect against such responses. It should also be noted that the therapeutic potential of current $5-\mathrm{HT}_{1 \mathrm{~A}}$ agonists suffers from some important limitations. Prominent among these is poor selectivity of the drugs with respect to crossreacting targets. Indeed, buspirone also acts as a dopamine D2 receptor antagonist (Peroutka, 1985), and sarizotan is a weak D2 receptor partial agonist (Bartoszyk et al., 2004; NewmanTancredi et al., 2005; Bruins Slot et al., 2006), and may act as a functional antagonist. This suggests again that high selectivity for $5-\mathrm{HT}_{1 \mathrm{~A}}$ receptors is an important requirement to avoid concurrent off-target blockade of dopamine receptors. Secondly, drugs such as eltoprazine, buspirone, and tandospirone possess only modest agonist efficacy at $5-\mathrm{HT}_{1 \mathrm{~A}}$ receptors. Thus, even at high doses, they are only able to partially activate the receptor (Newman-Tancredi et al., 2003), suggesting that optimal motor control by $5-\mathrm{HT}_{1 \mathrm{~A}}$ receptors may necessitate high-efficacy agonist stimulation. The novel $5-\mathrm{HT}_{1 \mathrm{~A}}$ receptor agonist, NLX101 (also known as F15599) constitutes a promising advance in view of its exceptional $5-\mathrm{HT}_{1 \mathrm{~A}}$ receptor selectivity, high agonist efficacy and "biased agonist" profile (Newman-Tancredi et al., 2009), potently activating post-synaptic cortical $5-\mathrm{HT}_{1 \mathrm{~A}}$ heteroreceptors (Llado-Pelfort et al., 2010). In vivo, NLX-101 exhibits pro-motor influence in rats with dopaminergic lesions, potent antidepressant-like properties (Assie et al., 2010), procognitive activity (Depoortere et al., 2010); and, in MeCP2 mice, reverses respiratory disturbance (Levitt et al., 2013), properties that would be desirable in a pharmacotherapy strategy for Rett syndrome.

\section{CONCLUSIONS}

The severe autonomic phenotype of Rett syndrome has the greatest impact on patient's health and quality of life, closely followed by motor deficits. $5-\mathrm{HT}_{1 \mathrm{~A}}$ agonists have shown promising ability to alleviate brainstem, extrapyramidal and mood dysfunction in pre-clinical studies. In particular, a new class of selective "biased agonists" that target post-synaptic heteroreceptors shows less potential for competing or undesirable side effects. However, further rigorous pre-clinical testing in different mouse models of Rett syndrome is needed, especially in regards to motor dysfunction. In mouse models, the syndrome is reversible if MeCP2 function is rescued, but a cure applicable to humans is uncertain and may be many years away. In the meantime, there is need for drug therapies that are tolerated upon long term treatment and capable of alleviating the life-threatening autonomic symptoms.

\section{AUTHOR CONTRIBUTIONS}

Ana P. Abdala and Adrian Newman-Tancredi drafted the manuscript; Ana P. Abdala, John M. Bissonnette, and Adrian Newman-Tancredi revised it critically for important intellectual content; and approved the final version to be published; and are accountable for all aspects of the work.

\section{ACKNOWLEDGMENTS}

Ana P. Abdala is funded by the International Rett Syndrome Foundation and the National Institutes of Health (R01 NS069220). John M. Bissonnette is funded by the Rett Syndrome Research Trust, the NewLife Foundation and the International Rett Syndrome Foundation.

\section{REFERENCES}

Abdala, A. P., Dutschmann, M., Bissonnette, J. M., and Paton, J. F. (2010). Correction of respiratory disorders in a mouse model of Rett syndrome. Proc. Natl. Acad. Sci. U.S.A. 107, 18208-18213. doi: 10.1073/pnas.1012104107

Abdala, A. P., Lioy, D. T., Garg, S. K., Knopp, S. J., Paton, J. F., and Bissonnette, J. M. (in press). Effect of sarizotan, a 5-HT and D2-like receptor agonist, on respiration in three mouse models of rett syndrome. Am. J. Respir. Cell Mol. Biol. doi: 10.1165/rcmb.2013-0372OC

Akimova, E., Lanzenberger, R., and Kasper, S. (2009). The serotonin$1 \mathrm{~A}$ receptor in anxiety disorders. Biol. Psychiatry 66, 627-635. doi: 10.1016/j.biopsych.2009.03.012

Andaku, D. K., Mercadante, M. T., and Schwartzman, J. S. (2005). Buspirone in Rett syndrome respiratory dysfunction. Brain Dev. 27, 437-438. doi: 10.1016/j.braindev.2004.09.011

Assie, M. B., Bardin, L., Auclair, A. L., Carilla-Durand, E., Depoortere, R., Koek, W., et al. (2010). F15599, a highly selective post-synaptic 5-HT(1A) receptor agonist: in-vivo profile in behavioural models of antidepressant and serotonergic activity. Int. J. Neuropsychopharmacol. 13, 1285-1298. doi: 10.1017/S1461145709991222

Bartoszyk, G. D., Van Amsterdam, C., Greiner, H. E., Rautenberg, W., Russ, H., and Seyfried, C. A. (2004). Sarizotan, a serotonin 5-HT1A receptor agonist and dopamine receptor ligand. 1. Neurochemical profile. J. Neural Transm. 111, 113-126. doi: 10.1007/s00702-003-0094-7

Besnard, S., Masse, F., Verdaguer, M., Cappelin, B., Meurice, J. C., and Gestreau, C. (2007). Time- and dose-related effects of three 5-HT receptor ligands on the genioglossus activity in anesthetized and conscious rats. Sleep Breath. 11, 275-284. doi: 10.1007/s11325-007-0107-0

Bezard, E., Tronci, E., Pioli, E. Y., Li, Q., Porras, G., Bjorklund, A., et al. (2013). Study of the antidyskinetic effect of eltoprazine in animal models of 
levodopa-induced dyskinesia. Mov. Disord. 28, 1088-1096. doi: 10.1002/mds. 25366

Bissonnette, J. M., Schaevitz, L. R., Knopp, S. J., and Zhou, Z. (2014). Respiratory phenotypes are distinctly affected in mice with common Rett syndrome mutations MeCP2 T158A and R168X. Neuroscience 267, 166-176. doi: 10.1016/j.neuroscience.2014.02.043

Bonifati, V., Fabrizio, E., Cipriani, R., Vanacore, N., and Meco, G. (1994). Buspirone in levodopa-induced dyskinesias. Clin. Neuropharmacol. 17, 73-82. doi: 10.1097/00002826-199402000-00008

Bortolozzi, A., Masana, M., Diaz-Mataix, L., Cortes, R., Scorza, M. C., Gingrich, J. A., et al. (2010). Dopamine release induced by atypical antipsychotics in prefrontal cortex requires 5-HT(1A) receptors but not 5-HT(2A) receptors. Int. J. Neuropsychopharmacol. 13, 1299-1314. doi: 10.1017/S1461145710 00009X

Bruins Slot, L. A., De Vries, L., Newman-Tancredi, A., and Cussac, D. (2006). Differential profile of antipsychotics at serotonin 5-HT1A and dopamine D2S receptors coupled to extracellular signal-regulated kinase. Eur. J. Pharmacol. 534, 63-70. doi: 10.1016/j.ejphar.2006.01.027

Carnevali, L., Mastorci, F., Audero, E., Graiani, G., Rossi, S., Macchi, E., et al. (2012). Stress-induced susceptibility to sudden cardiac death in mice with altered serotonin homeostasis. PLoS ONE 7:e41184. doi: 10.1371/journal.pone.0041184

Carotenuto, M., Esposito, M., D’Aniello, A., Rippa, C. D., Precenzano, F., Pascotto, A., et al. (2013). Polysomnographic findings in Rett syndrome: a case-control study. Sleep Breath. 17, 93-98. doi: 10.1007/s11325-012-0654-x

Celada, P., Bortolozzi, A., and Artigas, F. (2013). Serotonin 5-HT1A receptors as targets for agents to treat psychiatric disorders: rationale and current status of research. CNS Drugs 27, 703-716. doi: 10.1007/s40263-013-0071-0

Chahrour, M., and Zoghbi, H. Y. (2007). The story of Rett syndrome: from clinic to neurobiology. Neuron 56, 422-437. doi: 10.1016/j.neuron.2007.10.001

Chen, Y. H., Hou, L. L., and Wang, J. J. (2008). 5-HT1A/7 receptor agonist excites cardiac vagal neurons via inhibition of both GABAergic and glycinergic inputs. Acta Pharmacol. Sin. 29, 529-538. doi: 10.1111/j.1745-7254.2008.00745.x

Colpaert, F. C. (2006). 5-HT(1A) receptor activation: new molecular and neuroadaptive mechanisms of pain relief. Curr. Opin. Investig. Drugs 7, 40-47.

Corcoran, A. E., Richerson, G. B., and Harris, M. B. (2013). Serotonergic mechanisms are necessary for central respiratory chemoresponsiveness in situ. Respir. Physiol. Neurobiol. 186, 214-220. doi: 10.1016/j.resp.2013.02.015

Dawson, L. A., and Watson, J. M. (2009). Vilazodone: a 5-HT1A receptor agonist/serotonin transporter inhibitor for the treatment of affective disorders. CNS Neurosci. Ther. 15, 107-117. doi: 10.1111/j.1755-5949.2008.00067.x

Dempsey, J. A., Xie, A., Patz, D. S., and Wang, D. (2014). Physiology in medicine: obstructive sleep apnea pathogenesis and treatment-considerations beyond airway anatomy. J. Appl. Physiol. (1985) 116, 3-12. doi: 10.1152/japplphysiol.01054.2013

Depoortere, R., Auclair, A. L., Bardin, L., Colpaert, F. C., Vacher, B., and Newman-Tancredi, A. (2010). F15599, a preferential post-synaptic 5-HT1A receptor agonist: activity in models of cognition in comparison with reference 5-HT1A receptor agonists. Eur. Neuropsychopharmacol. 20, 641-654. doi: 10.1016/j.euroneuro.2010.04.005

Dhingra, R. R., Zhu, Y., Jacono, F. J., Katz, D. M., Galan, R. F., and Dick, T. E. (2013). Decreased Hering-Breuer input-output entrainment in a mouse model of Rett syndrome. Front. Neural Circuits 7:42. doi: 10.3389/fncir.2013.00042

Dolce, A., Ben-Zeev, B., Naidu, S., and Kossoff, E. H. (2013). Rett syndrome and epilepsy: an update for child neurologists. Pediatr. Neurol. 48, 337-345. doi: 10.1016/j.pediatrneurol.2012.11.001

Dupre, K. B., Ostock, C. Y., Eskow Jaunarajs, K. L., Button, T., Savage, L. M., Wolf, W., et al. (2011). Local modulation of striatal glutamate efflux by serotonin 1 A receptor stimulation in dyskinetic, hemiparkinsonian rats. Exp. Neurol. 229, 288-299. doi: 10.1016/j.expneurol.2011.02.012

Fiorino, F., Severino, B., Magli, E., Ciano, A., Caliendo, G., Santagada, V., et al. (in press). 5-HT receptor: an old target as a new attractive tool in drug discovery from central nervous system to cancer. J. Med. Chem. doi: 10.1021/ jm400533t

Fitzgerald, P. M., Jankovic, J., Glaze, D. G., Schultz, R., and Percy, A. K. (1990). Extrapyramidal involvement in Rett's syndrome. Neurology 40, 293-295. doi: 10.1212/WNL.40.2.293

Garcia-Garcia, A. L., Newman-Tancredi, A., and Leonardo, E. D. (2014). 5-HT(1A) [corrected] receptors in mood and anxiety: recent insights into autoreceptor versus heteroreceptor function. Psychopharmacology (Berl). 231, 623-636. doi: 10.1007/s00213-013-3389-x

Gokben, S., Ardic, U. A., and Serdaroglu, G. (2012). Use of buspirone and fluoxetine for breathing problems in Rett syndrome. Pediatr. Neurol. 46, 192-194. doi: 10.1016/j.pediatrneurol.2011.12.003

Gregoire, L., Samadi, P., Graham, J., Bedard, P. J., Bartoszyk, G. D., and Di Paolo, T. (2009). Low doses of sarizotan reduce dyskinesias and maintain antiparkinsonian efficacy of L-Dopa in parkinsonian monkeys. Parkinsonism Relat. Disord. 15, 445-452. doi: 10.1016/j.parkreldis.2008.11.001

Gross, C., Zhuang, X., Stark, K., Ramboz, S., Oosting, R., Kirby, L., et al. (2002). Serotonin1A receptor acts during development to establish normal anxiety-like behaviour in the adult. Nature 416, 396-400. doi: 10.1038/ 416396a

Guideri, F., Acampa, M., Blardi, P., De Lalla, A., Zappella, M., and Hayek, Y. (2004). Cardiac dysautonomia and serotonin plasma levels in Rett syndrome. Neuropediatrics 35, 36-38. doi: 10.1055/s-2004-815789

Guideri, F., Acampa, M., Diperri, T., Zappella, M., and Hayek, Y. (2001). Progressive cardiac dysautonomia observed in patients affected by classic Rett syndrome and not in the preserved speech variant. J. Child Neurol. 16, 370-373. doi: 10.1177/088307380101600512

Guideri, F., Acampa, M., Hayek, G., Zappella, M., and Di Perri, T. (1999). Reduced heart rate variability in patients affected with Rett syndrome. A possible explanation for sudden death. Neuropediatrics 30, 146-148. doi: 10.1055/s-2007973480

Hagebeuk, E. E., Bijlmer, R. P., Koelman, J. H., and Poll-The, B. T. (2012). Respiratory disturbances in rett syndrome: don't forget to evaluate upper airway obstruction. J. Child Neurol. 27, 888-892. doi: 10.1177/0883073811429859

Halbach, N. S., Smeets, E. E., Bierau, J., Keularts, I. M., Plasqui, G., Julu, P. O., et al. (2012). Altered carbon dioxide metabolism and creatine abnormalities in rett syndrome. JIMD Rep. 3, 117-124. doi: 10.1007/8904_2011_76

Hodges, M. R., Tattersall, G. J., Harris, M. B., McEvoy, S. D., Richerson, D. N., Deneris, E. S., et al. (2008). Defects in breathing and thermoregulation in mice with near-complete absence of central serotonin neurons. J. Neurosci. 28, 2495-2505. doi: 10.1523/JNEUROSCI.4729-07.2008

Huot, P., Fox, S. H., Newman-Tancredi, A., and Brotchie, J. M. (2011). Anatomically selective serotonergic type $1 \mathrm{~A}$ and serotonergic type $2 \mathrm{~A}$ therapies for Parkinson's disease: an approach to reducing dyskinesia without exacerbating parkinsonism? J. Pharmacol. Exp. Ther. 339, 2-8. doi: 10.1124/jpet.111. 184093

Ide, S., Itoh, M., and Goto, Y. (2005). Defect in normal developmental increase of the brain biogenic amine concentrations in the mecp2-null mouse. Neurosci. Lett. 386, 14-17. doi: 10.1016/j.neulet.2005.05.056

Iravani, M. M., Tayarani-Binazir, K., Chu, W. B., Jackson, M. J., and Jenner, P. (2006). In 1-methyl-4-phenyl-1,2,3,6-tetrahydropyridine-treated primates, the selective 5-hydroxytryptamine la agonist (R)-(+)-8-OHDPAT inhibits levodopa-induced dyskinesia but only withlincreased motor disability. J. Pharmacol. Exp. Ther. 319, 1225-1234. doi: 10.1124/jpet.106. 110429

Kannari, K., Kurahashi, K., Tomiyama, M., Maeda, T., Arai, A., Baba, M., et al. (2002). [Tandospirone citrate, a selective 5-HT1A agonist, alleviates L-DOPAinduced dyskinesia in patients with Parkinson's disease]. No To Shinkei 54, 133-137.

Katz, D. M., Berger-Sweeney, J. E., Eubanks, J. H., Justice, M. J., Neul, J. L., Pozzo-Miller, L., et al. (2012). Preclinical research in Rett syndrome: setting the foundation for translational success. Dis. Model. Mech. 5, 733-745. doi: $10.1242 / \mathrm{dmm} .011007$

Kerr, A. M., Armstrong, D. D., Prescott, R. J., Doyle, D., and Kearney, D. L. (1997). Rett syndrome: analysis of deaths in the British survey. Eur. Child Adolesc. Psychiatry 6(Suppl. 1), 71-74.

Kohler, M., Bloch, K. E., and Stradling, J. R. (2009). Pharmacological approaches to the treatment of obstructive sleep apnoea. Expert Opin. Investig. Drugs 18, 647-656. doi: 10.1517/13543780902877674

Kusserow, H., Davies, B., Hortnagl, H., Voigt, I., Stroh, T., Bert, B., et al. (2004). Reduced anxiety-related behaviour in transgenic mice overexpressing serotonin 1A receptors. Brain Res. Mol. Brain Res. 129, 104-116. doi: 10.1016/j.molbrainres.2004.06.028

Lehnert, H., Lombardi, F., Raeder, E. A., Lorenzo, A. V., Verrier, R. L., Lown, B., et al. (1987). Increased release of brain serotonin reduces vulnerability to ventricular fibrillation in the cat. J. Cardiovasc. Pharmacol. 10, 389-397. 
Leonardo, E. D., and Hen, R. (2008). Anxiety as a developmental disorder. Neuropsychopharmacology 33, 134-140. doi: 10.1038/sj.npp.1301569

Levitt, E. S., Hunnicutt, B. J., Knopp, S. J., Williams, J. T., and Bissonnette, J. M. (2013). A selective 5-HTla receptor agonist improves respiration in a mouse model of Rett syndrome. J. Appl. Physiol. (1985) 115, 1626-1633. doi: 10.1152/japplphysiol.00889.2013

Llado-Pelfort, L., Assie, M. B., Newman-Tancredi, A., Artigas, F., and Celada, P. (2010). Preferential in vivo action of F15599, a novel 5-HT(1A) receptor agonist, at postsynaptic 5-HT(1A) receptors. Br. J. Pharmacol. 160, 1929-1940. doi: $10.1111 / \mathrm{j} .1476-5381.2010 .00738 . \mathrm{x}$

Lo Iacono, L., and Gross, C. (2008). Alpha-Ca2+/calmodulin-dependent protein kinase II contributes to the developmental programming of anxiety in serotonin receptor 1A knock-out mice. J. Neurosci. 28, 6250-6257. doi: 10.1523/JNEUROSCI.5219-07.2008

Marin, C., Aguilar, E., Rodriguez-Oroz, M. C., Bartoszyk, G. D., and Obeso, J. A. (2009). Local administration of sarizotan into the subthalamic nucleus attenuates levodopa-induced dyskinesias in 6-OHDA-lesioned rats. Psychopharmacology (Berl). 204, 241-250. doi: 10.1007/s00213-008$1452-9$

McCall, R. B., Escandon, N. A., Harris, L. T., and Clement, M. E. (1994). Tolerance development to the vagal-mediated bradycardia produced by 5 -HT1A receptor agonists. J. Pharmacol. Exp. Ther. 271, 776-781.

McGill, B. E., Bundle, S. F., Yaylaoglu, M. B., Carson, J. P., Thaller, C., and Zoghbi, H. Y. (2006). Enhanced anxiety and stress-induced corticosterone release are associated with increased Crh expression in a mouse model of Rett syndrome. Proc. Natl. Acad. Sci. U.S.A. 103, 18267-18272. doi: 10.1073/pnas.0608702103

McMillen, B. A., Scott, S. M., and Davanzo, E. A. (1988). Reversal of neurolepticinduced catalepsy by novel aryl-piperazine anxiolytic drugs. J. Pharm. Pharmacol. 40, 885-887. doi: 10.1111/j.2042-7158.1988.tb06295.x

Meltzer, H. Y., and Sumiyoshi, T. (2008). Does stimulation of 5-HT(1A) receptors improve cognition in schizophrenia? Behav. Brain Res. 195, 98-102. doi: 10.1016/j.bbr.2008.05.016

Monti, J. M., and Monti, D. (2000). Role of dorsal raphe nucleus serotonin 5HT1A receptor in the regulation of REM sleep. Life Sci. 66, 1999-2012. doi: 10.1016/S0024-3205(99)00649-9

Mork, A., Brennum, L. T., Fallon, S. M., Bisulco, S., Frederiksen, K., BangAndersen, B., et al. (2009). "Pharmacological profile of Lu AA21004, a novel multitarget drug for the treatment of mood disorders," in Society for Neuroscience - 39th Annual Meeting (Chicago, IL).

Narkiewicz, K., Van De Borne, P. J., Pesek, C. A., Dyken, M. E., Montano, N., and Somers, V. K. (1999). Selective potentiation of peripheral chemoreflex sensitivity in obstructive sleep apnea. Circulation 99, 1183-1189. doi: 10.1161/01.CIR.99.9.1183

Newman-Tancredi, A. (2011). Biased agonism at serotonin 5-HT1A receptors: preferential postsynaptic activity for improved therapy of CNS disorders. Neuropsychiatry 1, 149-164. doi: 10.2217/Npy.11.12

Newman-Tancredi, A., Assie, M. B., Leduc, N., Ormiere, A. M., Danty, N., and Cosi, C. (2005). Novel antipsychotics activate recombinant human and native rat serotonin 5-HT1A receptors: affinity, efficacy and potential implications for treatment of schizophrenia. Int. J. Neuropsychopharmacol. 8, 341-356. doi: $10.1017 /$ S1461145704005000

Newman-Tancredi, A., Martel, J. C., Assie, M. B., Buritova, J., Lauressergues, E., Cosi, C., et al. (2009). Signal transduction and functional selectivity of F15599, a preferential post-synaptic 5-HT1A receptor agonist. Br. J. Pharmacol. 156, 338-353. doi: 10.1111/j.1476-5381.2008.00001.x

Newman-Tancredi, A., Rivet, J. M., Cussac, D., Touzard, M., Chaput, C., Marini, L., et al. (2003). Comparison of hippocampal G protein activation by 5-HT(1A) receptor agonists and the atypical antipsychotics clozapine and S16924. Naunyn Schmiedebergs Arch. Pharmacol. 368, 188-199. doi: 10.1007/s00210-0030788-2

Peroutka, S. J. (1985). Selective interaction of novel anxiolytics with 5hydroxytryptamine1A receptors. Biol. Psychiatry 20, 971-979. doi: 10.1016/ 0006-3223(85)90194-5

Phillips, A. G., Ahn, S., and Floresco, S. B. (2004). Magnitude of dopamine release in medial prefrontal cortex predicts accuracy of memory on a delayed response task. J. Neurosci. 24, 547-553. doi: 10.1523/JNEUROSCI.4653-03.2004

Ramirez, J. M., Ward, C. S., and Neul, J. L. (2013). Breathing challenges in Rett Syndrome: lessons learned from humans and animal models. Respir. Physiol. Neurobiol. 189, 280-287. doi: 10.1016/j.resp.2013.06.022
Ray, R. S., Corcoran, A. E., Brust, R. D., Kim, J. C., Richerson, G. B., Nattie, E., et al. (2011). Impaired respiratory and body temperature control upon acute serotonergic neuron inhibition. Science 333, 637-642. doi: 10.1126/science. 1205295

Richerson, G. B. (2004). Serotonergic neurons as carbon dioxide sensors that maintain pH homeostasis. Nat. Rev. Neurosci. 5, 449-461. doi: 10.1038/nrn1409

Richter, D. W., Manzke, T., Wilken, B., and Ponimaskin, E. (2003). Serotonin receptors: guardians of stable breathing. Trends Mol. Med. 9, 542-548. doi: 10.1016/j.molmed.2003.10.010

Roze, E., Cochen, V., Sangla, S., Bienvenu, T., Roubergue, A., Leu-Semenescu, S., et al. (2007). Rett syndrome: an overlooked diagnosis in women with stereotypic hand movements, psychomotor retardation, Parkinsonism, and dystonia? Mov. Disord. 22, 387-389. doi: 10.1002/mds.21276

Samaco, R. C., Mandel-Brehm, C., Chao, H. T., Ward, C. S., Fyffe-Maricich, S. L., Ren, J., et al. (2009). Loss of MeCP2 in aminergic neurons causes cell-autonomous defects in neurotransmitter synthesis and specific behavioral abnormalities. Proc. Natl. Acad. Sci. U.S.A. 106, 21966-21971. doi: 10.1073/pnas.0912257106

Samaco, R. C., McGraw, C. M., Ward, C. S., Sun, Y., Neul, J. L., and Zoghbi, H. Y. (2013). Female Mecp2(+/-) mice display robust behavioral deficits on two different genetic backgrounds providing a framework for pre-clinical studies. Hum. Mol. Genet. 22, 96-109. doi: 10.1093/hmg/dds406

Santana, N., Bortolozzi, A., Serrats, J., Mengod, G., and Artigas, F. (2004). Expression of serotonin $1 \mathrm{~A}$ and serotonin2A receptors in pyramidal and GABAergic neurons of the rat prefrontal cortex. Cereb. Cortex 14, 1100-1109. doi: 10.1093/cercor/bhh070

Shevtsova, N. A., Manzke, T., Molkov, Y. I., Bischoff, A., Smith, J. C., Rybak, I. A., et al. (2011). Computational modelling of 5-HT receptor-mediated reorganization of the brainstem respiratory network. Eur. J. Neurosci. 34, 1276-1291. doi: 10.1111/j.1460-9568.2011.07825.x

Smeets, E. E., Julu, P. O., Van Waardenburg, D., Engerstrom, I. W., Hansen, S., Apartopoulos, F., et al. (2006). Management of a severe forceful breather with Rett syndrome using carbogen. Brain Dev. 28, 625-632. doi: 10.1016/j.braindev.2006.04.010

Smith, J. C., Abdala, A. P., Borgmann, A., Rybak, I. A., and Paton, J. F. (2013). Brainstem respiratory networks: building blocks and microcircuits. Trends Neurosci. 36, 152-162. doi: 10.1016/j.tins.2012.11.004

Southall, D. P., Kerr, A. M., Tirosh, E., Amos, P., Lang, M. H., and Stephenson, J. B. (1988). Hyperventilation in the awake state: potentially treatable component of Rett syndrome. Arch. Dis. Child. 63, 1039-1048.

Stahl, S. M., Sommer, B., and Allers, K. A. (2011). Multifunctional pharmacology of flibanserin: possible mechanism of therapeutic action in hypoactive sexual desire disorder. J. Sex. Med. 8, 15-27. doi: 10.1111/j.1743-6109.2010. 02032.x

Stettner, G. M., Huppke, P., Brendel, C., Richter, D. W., Gartner, J., and Dutschmann, M. (2007). Breathing dysfunctions associated with impaired control of postinspiratory activity in Mecp2-/y knockout mice. J. Physiol. 579, 863-876. doi: 10.1113/jphysiol.2006.119966

Stettner, G. M., Zanella, S., Hilaire, G., and Dutschmann, M. (2008). 8-OH-DPAT suppresses spontaneous central apneas in the C57BL/6J mouse strain. Respir Physiol. Neurobiol. 161, 10-15. doi: 10.1016/j.resp.2007.11.001

Toward, M. A., Abdala, A. P., Knopp, S. J., Paton, J. F., and Bissonnette, J. M. (2013). Increasing brain serotonin corrects CO2 chemosensitivity in methylCpG-binding protein 2 (Mecp2)-deficient mice. Exp. Physiol. 98, 842-849. doi: 10.1113/expphysiol.2012.069872

Viemari, J. C., Roux, J. C., Tryba, A. K., Saywell, V., Burnet, H., Pena, F., et al. (2005). Mecp2 deficiency disrupts norepinephrine and respiratory systems in mice. J. Neurosci. 25, 11521-11530. doi: 10.1523/JNEUROSCI.437305.2005

Voituron, N., Menuet, C., Dutschmann, M., and Hilaire, G. (2010). Physiological definition of upper airway obstructions in mouse model for Rett syndrome. Respir. Physiol. Neurobiol. 173, 146-156. doi: 10.1016/j.resp.2010.07.006

Wadenberg, M. L. (1996). Serotonergic mechanisms in neuroleptic-induced catalepsy in the rat. Neurosci. Biobehav. Rev. 20, 325-339. doi: 10.1016/01497634(95)00057-7

Waters, K. A., Suresh, S., and Nixon, G. M. (2013). Sleep disorders in children. Med. J. Aust. 199, S31-S35. doi: 10.5694/mja13.10621

Weese-Mayer, D. E., Lieske, S. P., Boothby, C. M., Kenny, A. S., Bennett, H. L., and Ramirez, J. M. (2008). Autonomic dysregulation in young girls with 
Rett Syndrome during nighttime in-home recordings. Pediatr. Pulmonol. 43, 1045-1060. doi: 10.1002/ppul.20866

Weng, S. M., Bailey, M. E., and Cobb, S. R. (2011). Rett syndrome: from bed to bench. Pediatr. Neonatol. 52, 309-316. doi: 10.1016/j.pedneo.2011. 08.002

Wilken, B., Lalley, P., Bischoff, A. M., Christen, H. J., Behnke, J., Hanefeld, F., et al. (1997). Treatment of apneustic respiratory disturbance with a serotoninreceptor agonist. J. Pediatr. 130, 89-94. doi: 10.1016/S0022-3476(97)70315-9

Younes, M., Loewen, A. H., Ostrowski, M., Laprairie, J., Maturino, F., and Hanly, P. J. (2012). Genioglossus activity available via non-arousal mechanisms vs. that required for opening the airway in obstructive apnea patients. J. Appl. Physiol. (1985) 112, 249-258. doi: 10.1152/japplphysiol.003 12.2011

Zhang, X. L., Su, J. D., Cui, N. R., Gai, H. Y., Wu, Z. Y., and Jiang, C. (2011). The disruption of central CO2 chemosensitivity in a mouse model of Rett syndrome. Am. J. Physiol. Cell Physiol. 301, C729-C738. doi: 10.1152/ajpcell. 00334.2010
Conflict of Interest Statement: Adrian Newman-Tancredi has received consulting and/or speaker honoraria from pharmaceutical companies. He is Chief Scientific Officer and stockholder at Neurolixis.

Received: 11 April 2014; accepted: 12 May 2014; published online: 30 May 2014. Citation: Abdala AP, Bissonnette JM and Newman-Tancredi A (2014) Pinpointing brainstem mechanisms responsible for autonomic dysfunction in Rett syndrome: therapeutic perspectives for 5-HT $1 \mathrm{~A}$ agonists. Front. Physiol. 5:205. doi: 10.3389/fphys. 2014.00205

This article was submitted to Integrative Physiology, a section of the journal Frontiers in Physiology.

Copyright (c) 2014 Abdala, Bissonnette and Newman-Tancredi. This is an openaccess article distributed under the terms of the Creative Commons Attribution License (CC BY). The use, distribution or reproduction in other forums is permitted, provided the original author(s) or licensor are credited and that the original publication in this journal is cited, in accordance with accepted academic practice. No use, distribution or reproduction is permitted which does not comply with these terms. 